\title{
ALTERATIONS IN LIPID TRANSFER TO HIGH-DENSITY LIPOPROTEIN (HDL) AND ACTIVITY OF PARAOXONASE-1 IN HIV+ PATIENTS
}

\author{
Elaine Nunes DAMINELLI(1), Celso SPADA(1), Arício TREITINGER(1), Tatiane Vanessa OLIVEIRA(2), Maria da Conceição LATRILHA(2) \\ \& Raul Cavalcante MARANHÃO(2,3)
}

\begin{abstract}
SUMMARY
$\mathrm{HIV}^{+}$patients often develop alterations of the plasma lipids that may implicate in development of premature coronary artery disease. High-density lipoprotein (HDL) has an important role in preventing atherogenesis and the aim of this study was to investigate aspects of HDL function in $\mathrm{HIV}^{+}$patients. $\mathrm{HIV}^{+}$patients $(\mathrm{n}=48)$ and healthy control subjects $(\mathrm{n}=45)$ of both sexes with similar age were studied. Twenty-five were not being treated with antiretroviral agents, 13 were under reverse transcriptase inhibitor nucleosidic and non-nucleosidic (NRTI+NNRTI) and 10 were under NRTI + protease inhibitors (NRTI+PI) treatment. Paraoxonase 1 (PON1) activity and the transfer of free and esterified cholesterol, tryglicerides and phospholipids from a lipidic nanoemulsion to HDL were analyzed. In comparison with healthy controls, $\mathrm{HIV}^{+}$patients presented low PON-1 activity and diminished transfer of free cholesterol and tryglicerides. In contrast, phospholipid transfer was increased in those patients, whereas the transfer of cholesteryl esters was unchanged. NRTI+NNRTI increases the transfer of cholesteryl esters and triglycerides but in NRTI+PI there was no difference in respect to non-treated $\mathrm{HIV}^{+}$patients. HDL from $\mathrm{HIV}^{+}$patients has smaller antioxidant properties, as shown by lower PON-1 activity, and the transfer of lipids to this lipoprotein fraction is also altered, suggesting that HDL function is defective in those patients.
\end{abstract}

KEYWORDS: High-density lipoproteins; Lipid Transfer Protein; Paraoxonase-1; Lipids; HIV; AIDS.

\section{INTRODUCTION}

In $\mathrm{HIV}^{+}$and AIDS patients, dyslipidemias, including low levels of high-density lipoprotein (HDL) cholesterol, are often found. As the survival of those subjects is being increasingly prolonged by treatment, they are exposed to those important risk factors for coronary artery disease $(\mathrm{CAD})^{13}$. Indeed, it has been described that in $\mathrm{HIV}^{+}$patients the incidence of premature CAD increases. It has been reported that not only the HIV infection but also the antiretroviral treatment, especially with protease inhibitors, elicits dyslipidemias ${ }^{1,6,8,14}$.

HDL cholesterol levels in the plasma inversely correlate with the risk of developing CAD. HDL has several actions that are associated with the atheroprotection such as the role in cholesterol esterification and in the reverse cholesterol transport that promotes the removal of the sterol from the body tissues to the liver for elimination in the bile $^{2,15,23}$. Furthermore, HDL has antioxidant properties that are mediated mainly by paraoxonase 1 (PON1) action. This enzyme is predominantly associated with the HDL fraction and catalyzes the degradation of oxidized LDL phospholipids ${ }^{18}$. Other actions of HDL are the antiadhesive, anti-inflammatory and improvement of the vascular reactivity ${ }^{2,3}$.
In infection status HDL cholesterol levels are often decreased but the causes of this reduction are unknown. It had been previously found that HIV nef, a protein that enhances HIV replication and infectivity specifically inhibits the ABCA1 dependent cholesterol efflux and apo A1 lipidation that is linked with HDL production and role in reverse cholesterol transport. Inhibition of the ABCA1 protein complex leads to low HDL cholesterol levels ${ }^{7,22}$. HDL may play a role in defense against infection and immunity ${ }^{29}$.

HDL is constantly being remodeled and lipid transfers are essential for its role in the reverse cholesterol transport and in the esterification of cholesterol. Both processes are intertwined and are key for the cholesterol homeostasis in the organism ${ }^{28}$. Lipid transfers between lipoprotein classes are bidirectional and depend on the structure and concentration in the plasma of the donor and the acceptor lipoprotein, as well as the action of the transfer proteins, namely cholesteryl ester transfer protein (CETP) and phospholipid transfer protein (PLTP) ${ }^{16}$. Due to the fact that HDL is active in many antiatherogenic processes it has been recognized the importance of the systematic evaluation of the functional aspects of the lipoprotein, beyond the simple measurement of HDL cholesterol. In this study, the ability of HDL from $\mathrm{HIV}^{+}$patients to receive lipids such as free cholesterol (FC), 


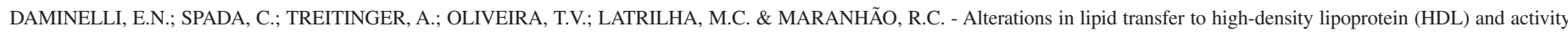
of paraoxonase-1 in $\mathrm{HIV}^{+}$patients. Rev. Inst. Med. trop. S. Paulo, 50(4): 223-227, 2008.

cholesteryl esters (CE), phospholipids (PL), and triglycerides (TG) as well as the PON1 activity were approached in $\mathrm{HIV}^{+}$patients under different treatment regimens and in patients that were not being treated for the disease.

\section{MATERIALS AND METHODS}

Study population: Forty-eight $\mathrm{HIV}^{+}$patients of both sexes and without diagnosed co-infections as hepatitis-B (HBV) and hepatitis-C (HCV) were studied and compared with 45 HIV serum negative healthy control subjects of similar age range and with total plasma cholesterol $<240 \mathrm{mg} / \mathrm{dL}$ and triglycerides $<200 \mathrm{mg} / \mathrm{dL}^{27}$.

Exclusion criteria were history of diabetes mellitus or previous treatment with antidiabetic agents, hypocholesteremic agents, antihypertensive medications and antioxidants; reported use of testosterone, estrogen, growth hormone, or other steroids in the past six months. Women using oral contraceptives were also excluded.

Their physical characteristics and laboratorial data are shown in Table 1. The group of $\mathrm{HIV}^{+}$patients was further separated in three distinct subgroups:

1) Non-treated, patients without antiretroviral treatment.

2) NRTI+NNRTI, patients who were being treated with nucleosidic reverse transcriptase inhibitors (NRTI) and non-nucleosidic reverse transcriptase inhibitors (NNRTI) (efavirenz, lamivudine, nevirapine, stavudine or zidovudine).

3) NRTI+PI, patients that were being treated with both nucleosidic reverse transcriptase inhibitors and protease inhibitors (PI) (atazanavir, lopinavir, nelfinavir, ritonavir or saquinavir).

Groups NRTI+NNRTI and NRTI+PI were being treated for at least the last six months. All the participants provided fully informed consent to participate in the study that was approved by the Ethics Committee of the Medical School Hospital of the Federal University of Santa Catarina.

Blood biochemical analysis: Blood samples were collected after a 12 hour fast and alcohol abstinence. Plasma total cholesterol (CHODPAP; Roche, Basel, SUI), triacylglycerols (Triglyceride Rapid; Roche, Basel, SUI) and glucose (Dimension ${ }^{\circledR}$ clinical chemistry system, Dade Behring Inc., Newark, USA) were determined by commercial enzymatic methods using a Cobas Mira analyzer (Roche). HDL cholesterol (HDLC) was measured after precipitation of the very low density lipoproteins (VLDL) and LDL with HDL Reagent ROCHE (method phosphotungsten acid: $\mathrm{MgCl}_{2}$ ) with automatic equipment. LDL-C was estimated by the Friedewald formula ${ }^{12}$.

HIV virus load was determined by use of the Nuclisens HIV-1 QT test (Organon Teknika BV, Boxtel, Netherland) by methodology Nucleic Acid Sequence-based Amplification. CD4+, T cell and CD8+ T cell counts were determined by FACscan flow cytometry (Becton Dickinson, San Jose, CA), utilizing the assembly reactivate with monoclonal antibodies anti CD4/CD3 and anti CD8/CD3 (Becton Dickinson, San Jose, CA).
Paraoxonase (PON1) activity: PON1 activity was measured by adding serum to $1 \mathrm{~mL}$ Tris-HCl buffer (100 mmol/L, $\mathrm{pH}$ 8.0) containing $2 \mathrm{mmol} / \mathrm{L} \mathrm{CaCl}_{2}$ and $5.5 \mathrm{mmol} / \mathrm{L}$ paraoxon (Sigma Chemical Company, London, Eng). The generation of p-nitrophenol was measured at 405 $\mathrm{nm}$, at $37{ }^{\circ} \mathrm{C}$ in a microplate reader (Bio-Rad, Benchmark, JPN $)^{17}$.

Lipid transfer from a donor artificial nanoemulsion to HDL: The preparation of the nanoemulsion from a lipid mixture by prolonged ultrasonic irradiation followed by ultracentrifugation was performed as described elsewhere ${ }^{21}$.

Radioactive lipids were purchased from Amersham International (Amersham, Little Chalfont, Buckinghanshier, UK) and were added to the lipid mixtures. Two sets of nanoemulsions were prepared, one labeled with ${ }^{3} \mathrm{H}$-cholesteryl oleate and ${ }^{14} \mathrm{C}$-phosphatidylcholine and the other with ${ }^{3} \mathrm{H}$-triolein and ${ }^{14} \mathrm{C}$-cholesterol.

The assay consisted in the incubation of the radioactively labeled nanoemulsion with whole plasma followed by chemical precipitation of the apo B containing lipoproteins and the nanoemulsion. Finally, the radioactive counting for the lipids that shifted from the nanoemulsion to HDL was performed in a Packard 1600 TR model Liquid Scintillation Analyzer (California, USA) by addition of a scintillation solution (Packard BioScience, Groeningen, NED) to the HDL-containing supernatant.

To assay for the transfer of the nanoemulsion radioactive lipids to HDL, blood samples were collected from the subjects into $0.15 \% \mathrm{Na}_{2}$ EDTA containing glass tubes and plasma was obtained by $15 \mathrm{~min}$ centrifugation at $2,500 \mathrm{rpm}$ at $4{ }^{\circ} \mathrm{C}$. Test tubes with the plasma samples $(0.2 \mathrm{~mL})$ and $0.05 \mathrm{~mL}$ nanoemulsion labeled with ${ }^{3} \mathrm{H}$-cholesteryl oleate and ${ }^{14} \mathrm{C}$-phosphatidylcholine or with ${ }^{3} \mathrm{H}$-triolein and ${ }^{14} \mathrm{C}$-cholesterol were placed in a shaking bath and incubated for $60 \mathrm{~min}$ at $37{ }^{\circ} \mathrm{C}$. Then, $0.250 \mathrm{~mL}$ solution with $0.02 \%$ dextran sulfate (50,000 M.W.) and 0.3 $\mathrm{mol} / \mathrm{L} \mathrm{MgCl}_{2}$ was added to the tubes and vortexed by $30 \mathrm{~s}$. Samples were centrifuged at $3,000 \mathrm{rpm}$ for $10 \mathrm{~min}$ and $0.250 \mathrm{~mL}$ of the obtained supernatant containing the HDL plasma fraction were transferred to vials with scintillation solution (Packard BioScience, Groeningen, NED), vigorously shaken and left to stand for at least $45 \mathrm{~min}$. Radioactivity was determined in a Packard 1600 TR model Liquid Scintillation Analyzer (California, USA). HDL acceptance of the nanoemulsion lipids was calculated as the $\%$ of a given labeled lipid in the nanoemulsion found in the HDL plasma fraction after the $60 \mathrm{~min}$ incubation period.

Statistical analyses: Comparison of all data was performed using the GraphPad Prism for Windows software (GraphPad, San Diego, CA). The comparison between the data from $\mathrm{HIV}^{+}$patients and control subjects was performed by unpaired Student's t-test and the data of the three $\mathrm{HIV}^{+}$subgroups were analyzed by Kruskal-Wallis nonparametric ANOVA test. Differences were considered significant when $p$ value $<0.05$. All data were expressed as mean \pm standard deviation (SD).

\section{RESULTS}

Table 1 shows that the Body Mass Index (BMI) of the $\mathrm{HIV}^{+}$patients was smaller than that of the control subjects. Regarding the plasma 
Table 1

Individual physical characteristics and plasma lipids

\begin{tabular}{lccc}
\hline Parameters & Controls & $\mathrm{HIV}^{+}$ & $p$ \\
\hline No. of subjects $(\mathrm{M} / \mathrm{F})$ & $45(16 / 29)$ & $48(22 / 26)$ & \\
Age $($ years) & $38 \pm 9$ & $37 \pm 8$ & 0.71 \\
Weight $(\mathrm{kg})$ & $70.4 \pm 14.8$ & $63.6 \pm 10.3$ & 0.01 \\
Height $(\mathrm{m})$ & $1.64 \pm 0.1$ & $1.70 \pm 0.1$ & 0.09 \\
BMI $\left(\mathrm{kg} / \mathrm{m}^{2}\right)$ & $25.8 \pm 3.7$ & $22.7 \pm 3.0$ & 0.0001 \\
Cholesterol (mg/dL) & & & \\
$\quad$ Total & $191 \pm 33$ & $164 \pm 30$ & 0.0001 \\
$\quad$ HDL & $41 \pm 10$ & $43 \pm 13$ & 0.44 \\
$\quad$ LDL & $127 \pm 30$ & $101 \pm 21$ & $<0.0001$ \\
Triglycerides $(\mathrm{mg} / \mathrm{dL})$ & $116 \pm 39$ & $99 \pm 32$ & 0.03 \\
PON1 $\left(\mathrm{nmol} . \mathrm{min}^{-1} . \mathrm{mL}^{-1}\right)$ & $71.8 \pm 37.4$ & $44.3 \pm 38.6$ & 0.001 \\
\hline
\end{tabular}

BMI: Body Mass Index; HDL: high-density lipoprotein; LDL: low-density lipoprotein; PON1: paraoxonase 1. Results are expressed as mean $\pm \mathrm{SD}, p<0.05$ (unpaired $t$-test).

lipids, the total and LDL cholesterol as well as the triglyceride values of the $\mathrm{HIV}^{+}$patients were smaller than those of the controls.

HDL cholesterol did not differ between the two groups. Table 1 also shows that PON 1 activity was smaller in $\mathrm{HIV}^{+}$than in controls.

Figure 1 shows the percentage of labeled lipids that was transferred from the nanoemulsion to HDL. $\mathrm{HIV}^{+}$patients show an increase in the transfer of PL when compared control subjects $(23.4 \pm 1.6 \%$ and 17.5 \pm 0.9 , respectively), whereas the transfer of $\mathrm{FC}$ and $\mathrm{TG}$ in $\mathrm{HIV}^{+}$patients

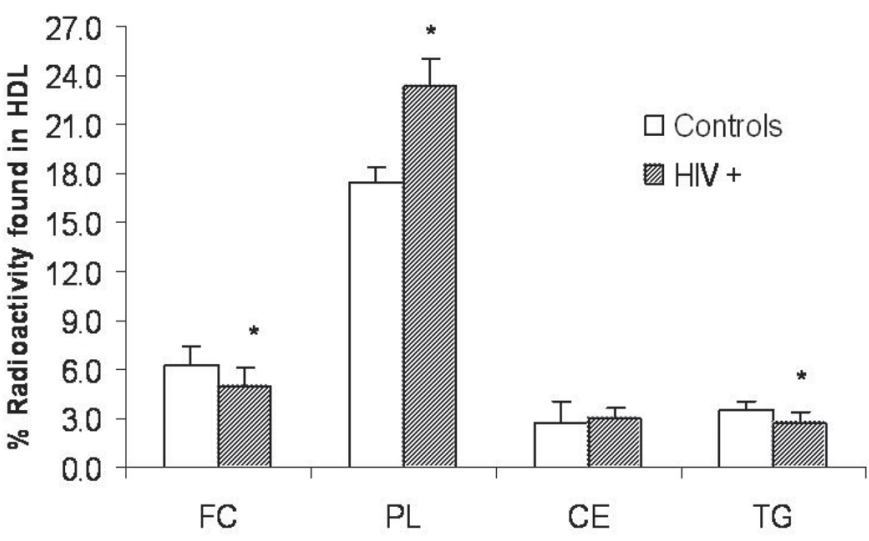

Fig. 1 - Percentage of the labeled lipids transferred from the lipidic nanoemulsion to the HDL fraction. Comparisons between $\mathrm{HIV}^{+}$vs control groups: * $p<0.0001$ (unpaired $t$-test). Results are expressed as mean $\pm \mathrm{SD} . \mathrm{FC}=$ free cholesterol; $\mathrm{PL}=$ phoshpolipid; $\mathrm{CE}=$ cholesteryl esters, $\mathrm{TG}=$ triglycerides

was smaller $(6.3 \pm 1.1$ vs. $5.0 \pm 1.1 \%$ and $3.5 \pm 0.6$ vs. $2.7 \pm 0.7 \%$, respectively). On the other hand, no difference in $\mathrm{CE}$ transfer was observed between cases and controls.

Table 2 shows comparisons among the subgroups of $\mathrm{HIV}^{+}$patients. HDL-cholesterol was greater in the NRTI+NNRTI than in non-treated and NRTI+PI subgroups and also greater than in the control HIV negative subjects. However, LDL cholesterol, triglycerides and PON1 were similar among the three subgroups of $\mathrm{HIV}^{+}$patients. Regarding the data on lipid transfer to HDL, the PL and FC transfer were not

Table 2

BMI, glucose, blood lipids, PON1 activity and transfer of triglycerides (TG), free cholesterol (FC), cholesteryl esters (CE) and phospholipids (PL) from the lipidic nanoemulsion to the HDL fraction in patients without antiretroviral therapy (non-treated), with nucleosidic reverse transcriptase inhibitors (NRTI) and nonnucleosidic reverse transcriptase inhibitors (NNRTI) or with protease inhibitors (PI)

\begin{tabular}{|c|c|c|c|}
\hline Parameters & $\begin{array}{c}\text { Non-treated } \\
n=25\end{array}$ & $\begin{array}{l}\text { NRTI with NNRTI } \\
n=13\end{array}$ & $\begin{array}{c}\text { NRTI with PI } \\
n=10\end{array}$ \\
\hline BMI $\left(\mathrm{kg} / \mathrm{m}^{2}\right)$ & $23.3 \pm 3.5$ & $22.4 \pm 2.3$ & $21.4 \pm 2.0$ \\
\hline Viral Load (RNA copies/mL) & $25740 \pm 57300$ & $277 \pm 610$ & $23186 \pm 65878$ \\
\hline CD4 cell count $\left(\right.$ cells $\left./ \mathrm{mm}^{3}\right)$ & $435 \pm 218$ & $450 \pm 190$ & $429 \pm 365$ \\
\hline CD8 cell count (cells $\left./ \mathrm{mm}^{3}\right)$ & $1076 \pm 873$ & $802 \pm 328$ & $1091 \pm 528$ \\
\hline Glucose $(\mathrm{mg} / \mathrm{dL})$ & $84 \pm 9$ & $102 \pm 33^{\S}$ & $79 \pm 11 * *$ \\
\hline \multicolumn{4}{|l|}{ Cholesterol (mg/dL) } \\
\hline Total & $159 \pm 27$ & $180 \pm 27$ & $154 \pm 34$ \\
\hline HDL & $39 \pm 8$ & $53 \pm 16^{\S}$ & $38 \pm 10^{*}$ \\
\hline LDL & $100 \pm 20$ & $106 \pm 19$ & $97 \pm 27$ \\
\hline Triglycerides (mg/dL) & $98 \pm 33$ & $103 \pm 29$ & $98 \pm 37$ \\
\hline PON1(nmol.min $\left.{ }^{-1} \cdot \mathrm{mL}^{-1}\right)$ & $45.7 \pm 36.9$ & $54.8 \pm 42.9$ & $33.5 \pm 37.9$ \\
\hline \multicolumn{4}{|l|}{ Lipid transfers $(\%)$} \\
\hline Triglycerides & $2.6 \pm 0.8$ & $3.1 \pm 0.6^{\S}$ & $2.1 \pm 0.3^{* *}$ \\
\hline Free Cholesterol & $5.0 \pm 1.1$ & $5.7 \pm 1.0$ & $4.3 \pm 1.0^{* *}$ \\
\hline Cholesteryl esters & $2.9 \pm 0.7$ & $3.4 \pm 0.6^{\S}$ & $2.8 \pm 0.7 *$ \\
\hline Phospholipids & $23.6 \pm 1.6$ & $23.8 \pm 1.3$ & $22.7 \pm 1.6$ \\
\hline
\end{tabular}

BMI: Body Mass Index; PON1: paraoxonase 1. Results expressed as mean \pm SD. $* p<0.05, * * p<0.01$ compared to NRTI with NNRTI (Kruskal-Wallis nonparametric ANOVA test); ${ }^{\S} p<0.05$ compared to non-treated (Kruskal-Wallis nonparametric ANOVA test). 


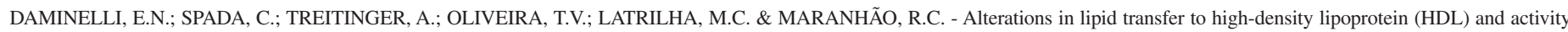
of paraoxonase-1 in $\mathrm{HIV}^{+}$patients. Rev. Inst. Med. trop. S. Paulo, 50(4): 223-227, 2008.

different between non-treated and NRTI+NNRTI patients, but the CE and TG transfer were greater in the NRTI+NNRTI than in the nontreated group. However, when protease inhibitors were added to the treatment, in the NRTI+PI group, HDL cholesterol diminished and all the parameters of lipid transfer became altered, with the exception of PL transfer.

\section{DISCUSSION}

In this study, the $\mathrm{HIV}^{+}$group of patients showed LDL cholesterol and triglyceride concentration in the plasma smaller than that of the control HIV negative subjects, whereas HDL cholesterol was equal. Indeed, $\mathrm{HIV}^{+}$patients often show diminished LDL cholesterol ${ }^{10,25}$, but triglycerides are generally described as increased in $\mathrm{HIV}^{+9,10}$, in contrast with the results of this study. However, increased triglyceride concentration leads to HDL cholesterol diminution ${ }^{5}$, and the fact that triglycerides were not increased in our $\mathrm{HIV}^{+}$group ultimately facilitates the analysis of the HDL status.

The three subgroups of $\mathrm{HIV}^{+}$patients did not differ among them in respect to LDL cholesterol. HDL cholesterol, however, was greater in the NRTI+NNRTI subgroup when compared with NRTI+PI, non-treated $\mathrm{HIV}^{+}$patients and also with the values of the HIV negative group. It was also reported in other studies that treatment with NRTI+NNRTI increases HDL cholesterol whereas addition of PI in the treatment leads to decrease in this parameter ${ }^{4,26}$.

PON 1 activity that is associated with the ability of HDL to prevent the accumulation of lipid peroxides on LDL and in the vessel wall ${ }^{19}$. The diminution of PON 1 in $\mathrm{HIV}^{+}$confirms the findings of PARRA et $a l .{ }^{24}$, both treated and non-treated patients.

The ability to receive lipids is a fundamental property of HDL. HDL stabilizes the plasma cholesterol pool by promoting cholesterol esterification, a process that is catalyzed by LCAT using apo A1, that is mostly contained in the HDL fraction, as a co-factor. By producing a completely apolar molecule, esterification of the cholesterol localized in the particle surface monolayer results in shift of the compound to the particle core, where it is isolated from the contact with the aqueous medium. By receiving cholesterol from cells and other lipoproteins and sending esterified cholesterol to other lipoprotein classes and to hepatocytes for excretion in the bile, HDL plays is crucial role in the reverse cholesterol transport ${ }^{16}$. Transfer of esterified cholesterol from HDL to other lipoprotein classes is mediated by CETP. Reception of phospholipids is also important for the HDL formation and remodeling and triglycerides are also exchanged between triglyceride rich lipoproteins such as VLDL and $\mathrm{HDL}^{30}$. This study shows that the ability of HDL to receive lipids, a fundamental aspect of the metabolism of this lipoprotein, is disturbed in $\mathrm{HIV}^{+}$patients compared with the HIV negative subjects. Those alterations, characterized by smaller transfer of free cholesterol and triglycerides and increase in the transfer of phospholipids from the lipid nanoparticles to HDL may cause or be consequent of disturbances in the dynamics of the HDL metabolism and the function of the lipoprotein in the plasma cholesterol stabilization and reverse transport. On the other hand, compared to the $\mathrm{HIV}^{+}$nontreated patients, treatment with NRTI+NNRTI increased the transfer to HDL of cholesteryl esters and triglyceride. In the group treated with the NRTI+PI scheme, lipid transfer to HDL was unchanged. Those differences in lipid transfer to HDL in response to different treatment regimens are presumably related to the effect on lipid metabolism by those drugs. In this respect, compared with NRTI+NNRTI, PI treatment worsens the lipid profile $4,20,26,31$.

The disturbances of HDL metabolism in $\mathrm{HIV}^{+}$found in this study can be at least partially attributed to cytokine release consequent to the infectious and inflammatory process. Those cytokines can diminish HDL and modify the HDL composition and function, such as the antioxidant properties of the lipoprotein ${ }^{11,24,32}$. Cytokine release in infectious and inflammatory processes also results in diminished HDL uptake by cells, by reducing the expression of ABCA1 system that helps in the removal of free cholesterol from the cells to the HDL particles ${ }^{11}$. Those changes may elicit alterations in the ability of HDL to receive lipids, as observed in this study and in the shift of lipids from HDL to other lipoproteins.

In conclusion, in the $\mathrm{HIV}^{+}$population sample studied here PON1 activity and the ability of HDL to receive lipids were altered. This suggests that functions of this uniquely protective lipoprotein can be disturbed in those patients.

\section{RESUMO}

\section{Alterações na transferência de lípides para a lipoproteína de alta densidade (HDL) e atividade da paroxonase $1 \mathrm{em}$ pacientes $\mathrm{HIV}^{+}$}

Pacientes $\mathrm{HIV}^{+}$freqüentemente desenvolvem alterações no metabolismo de lípides que podem influir no desenvolvimento de doença arterial coronária. A lipoproteína de alta densidade (HDL) tem papel importante na prevenção da aterogênese. Para investigar aspectos funcionais da $\mathrm{HDL}$ na doença, foram estudados 48 pacientes $\mathrm{HIV}^{+} \mathrm{e}$ 45 indivíduos-controle saudáveis de ambos os sexos, com idade semelhantes. Vinte e cinco pacientes $\mathrm{HIV}^{+}$não recebiam terapia antirretroviral, 13 estavam sob tratamento com inibidores nucleosídicos de transcriptase reversa e não-nucleosídicos (NRTI+NNRTI) e 10 sob tratamento com NRTI e inibidor de protease (NRTI+PI). Analisou-se a atividade da paroxonase 1 e a transferência de colesterol livre e esterificado, triglicérides e fosfolipídios de uma nanoemulsão lipídica para a HDL. Pacientes $\mathrm{HIV}^{+}$apresentaram menor atividade da paroxonase 1 e menor transferência de colesterol livre e triglicérides em relação aos indivíduos saudáveis. A transferência de fosfolipídios foi maior nesses pacientes, mas a transferência de éster de colesterol foi similar. NRTI+NNRTI aumenta a transferência de éster de colesterol e triglicérides, mas em NRTI+PI não houve diferença comparando com os pacientes $\mathrm{HIV}^{+}$não tratados. A $\mathrm{HDL}$ de pacientes $\mathrm{HIV}^{+}$tem propriedades antioxidantes reduzidas, evidenciada pela menor atividade da paraxonase 1, e transferência de lipídios alterada, sugerindo que a HDL apresente função defeituosa nestes pacientes.

\section{ACKNOWLEDGMENTS}

This study was supported by Fundação de Amparo à Pesquisa do Estado de São Paulo (FAPESP), São Paulo, Brazil. Dr. Maranhão is a Research Awardee of Conselho Nacional de Desenvolvimento Científico e Tecnológico (CNPq), Brasília, Brazil. 


\section{REFERENCES}

1. ANDRADE, A.C.O. \& COTTER, B.R. - Endothelial function and cardiovascular diseases in HIV infected patient. Braz. J. infect. Dis., 10: 139-145, 2006

2. BARTER, P.; KASTELEIN, J.; NUNN, A.; HOOBS, R \& FUTURE FORUM EDITORIAL BOARD - High-density lipoproteins (HDLs) and atherosclerosis, the unanswered questions. Atherosclerosis, 168: 195-211, 2003.

3. BARTER, P.J.; NICHOLLS, S.; RYE, K.A. et al. - Antiinflammatory properties of HDL. Circulat. Res., 95: 764-772, 2004.

4. BERGERSEN, B.M. - Cardiovascular risk in patients with HIV infection: impact of antiretroviral therapy. Drugs, 66: 1971-1987, 2006.

5. BRINTON, E.A.; EISENBERG, S. \& BRESLOW, J.L. - Increased apo A-I and apo A-II fractional catabolic rate in patients with low high density lipoprotein-cholesterol levels with or without hypertriglyceridemia. J. clin. Invest., 87: 536-544, 1991.

6. CALZA, L.; MANFREDI, R. \& CHIODO, F. - Dyslipidaemia associated with antiretroviral therapy in HIV-infected patients. J. Antimicrob. Chemother., 53: 1014, 2004.

7. CARR, A. \& ORY, D. - Does HIV cause cardiovascular disease? PLoS Med., 3(11): 1986-1987, 2006.

8. CARAMELLI, B.; BERNOCHE, C.Y.S.M.; SARTORI, A.M.C. et al. - Hyperlipidemia related to the use of HIV-protease inhibitors: natural history and results of treatment with fenofibrate. Braz. J. infect. Dis., 5: 332-338, 2001.

9. CHANU, B. \& VALENSI, P. - Les désordres lipidiques des patients atteints d'affections causées par le VIH. Presse méd., 34: 1087-1094, 2005.

10. CROOK, M.A. \& MIR, N. - Abnormal lipids and the acquired immunodeficiency syndrome: is there a problem and what should we do about it? Int. J. STD AIDS, 10: $353-356,1999$

11. ESTEVE, E.; RICART, W. \& FERNANDEZ-REAL, J.M. - Dyslipidemia and inflammation: an evolutionary conserved mechanism. Clin. Nutr., 24: 16-31, 2005.

12. FRIEDEWALD, W.T.; LEVY, R.I. \& FREDRICKSON, D.S. - Estimation of the concentration of low-density lipoprotein cholesterol in plasma, without use of the preparative ultracentrifuge. Clin. Chem., 18: 499-502, 1972.

13. HADIGAN, C.; MEIGS, J.B.; CORCORAN, C. et al. - Metabolic abnormalities and cardiovascular disease risk factors in adults with human immunodeficiency virus infection and lipodystrophy. Clin. infect. Dis., 32: 130-139, 2001.

14. HUI, D.Y. - Effects of HIV protease inhibitor therapy on lipid metabolism. Progr. Lipidi. Res., 42: 81-92, 2003.

15. KONTUSH, A. \& CHAPMAN, M.J. - Functionally defective high-density lipoprotein: a new therapeutic target at the crossroads of dyslipidemia, inflammation, and atherosclerosis. Pharmacol. Rev., 58: 342-374, 2006.

16. LEWIS, G.F. \& RADER, D.J. - New insights into the regulation of HDL metabolism and reverse cholesterol transport. Circulat. Res., 96: 1221-1232, 2005.

17. MACKNESS, M.I.; HARTY, D.; BHATNAGAR, D. et al. - Serum paraoxonase activity in familial hypercholesterolaemia and insulin-dependent diabetes mellitus. Atherosclerosis, 86: 193-199, 1991.
18. MACKNESS, M.I.; MACKNESS, B. \& DURRINGTON, P.N. - Paraoxonase and coronary heart disease. Atherosclerosis Suppl., 3(4): 49-55, 2002.

19. MACKNESS, M. \& MACKNESS, B. - Paraoxonase 1 and atherosclerosis: is the gene or the protein more important? Free rad. Biol. Med., 37: 1317-1323, 2004

20. MANFREDI, R. \& CHIODO, F. - Disorders of lipid metabolism in patients with HIV disease treated with antiretroviral agents: frequency, relationship with administered drugs, and role of hypolipidaemic therapy with bezafibrate. J. Infect., 42: 181-188, 2001.

21. MARANHÃO, R.C.; CESAR, T.B.; PEDROSO-MARIANI, S.R.; HIRATA, M.H. \& MESQUITA, C.H. - Metabolic behavior in rats of a nonprotein microemulsion resembling low-density. Lipids, 28: 691-696, 1993.

22. MUJAWAR, Z.; ROSE, H.; MORROW, M.P. et al. - Human immunodeficiency virus impairs reverse cholesterol transport from macrophages. PLoS Biol., 4(11): 19701983,2006

23. OHASHI, R.; MU, H.; WANG, X.; YAO, O. \& CHENG, C. - Reverse cholesterol transport and cholesterol efflux in atherosclerosis. QJM, 98: 845-856, 2005.

24. PARRA, S.; ALONSO-VILLAVERDE, C.; COLL, B. et al. - Serum paraoxonase-1 activity and concentration are influenced by human immunodeficiency virus infection. Atherosclerosis, 194: 175-181, 2007.

25. RIDDLER, S.A.; SMIT, E.; COLE, S.R. et al. - Impact of HIV infection and HAART on serum lipids in men. J. Amer. med. Ass., 289: 2978-2982, 2003.

26. ROSE, H.; WOOLLEY, I.; HOY, J. et al. - HIV infection and high-density lipoprotein the effect of the disease vs the effect of treatment. Metabolism, 55: 90-95, 2006.

27. SANTOS, R.D., coord. - III Diretrizes Brasileiras Sobre Dislipidemias e Diretriz de Prevençäo da Aterosclerose do Departamento de Aterosclerose da Sociedade Brasileira de Cardiologia. Arq. bras. Cardiol., 77(supl. 3): 1-48, 2001.

28. SVIRIDOV, D. \& NESTEL, P. - Dynamics of reverse cholesterol transport: protection against atherosclerosis. Atherosclerosis, 161: 245-254, 2002

29. THAVEERATITHAM, P.; PLENGPANICH, W.; NAEN-UDORN, W.; PATUMRAJ, S \& KHOVIDHUNKIT, W. - Effects of human apolipoprotein A-I on endotoxininduced leukocyte adhesion on endothelial cells in vivo and on the growth of Escherichia coli in vitro. J. Endotoxin Res., 13: 58-64, 2007.

30. WANG, M. \& BRIGGS, M.R. - HDL: the metabolism, function, and therapeutic importance. Chem. Rev., 104: 119-137, 2004.

31. YOUNG, J.; WEBER, R.; RICKENBACH, M. et al. - Lipid profiles for antiretroviralnaive patients starting PI- and NNRTI-based therapy in the Swiss HIV Cohort Study. Antivir. Ther., 10: 585-591, 2005.

32. ZANGERLE, R.; SARCLETTI, M.; GALLATI, H. et al. - Decreased plasma concentrations of HDL cholesterol in HIV-infected individuals are associated with immune activation. J. acquir. Immune Defic. Syndr., 7: 1149-1156, 1994.

Received: 21 December 2007

Accepted: 15 July 2008 